\title{
High Efficient Extraction of Tryptophan Using Deep Eutectic Solvent-based Aqueous Biphasic Systems
}

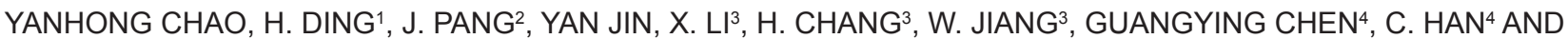 \\ W. $\mathrm{ZHU}^{3 *}$ \\ School of Pharmacy, Jiangsu University, Zhenjiang 212013, ${ }^{1}$ Affiliated People's Hospital of Jiangsu University, Zhenjiang \\ 212002, ${ }^{2}$ Henan Engineering Research Center of Industrial Circulating Water Treatment, College of Chemistry and Chemical \\ Engineering, Henan University, Kaifeng 475004, ${ }^{3}$ School of Chemistry and Chemical Engineering, Jiangsu University, \\ Zhenjiang 212013, ${ }^{4}$ Key Laboratory of Tropical Medicinal Plant Chemistry of Education, Hainan Normal University, Haikou \\ 571158 , P. R. China
}

Chao et al.: Extraction of Tryptophan with Eutectic Solvent-based Aqueous Biphasic Systems

\begin{abstract}
Deep eutectic solvent-based aqueous biphasic systems were established as greener replacements of organic solvents for the extraction of amino acid in this work. Choline chloride/polyethylene glycol 2000-based deep eutectic solvent was synthesized and characterized by element analysis, thermogravimetric analysis, and Fourier-transform infrared spectroscopy. The phase diagrams of deep eutectic solvent+salt $\left(\mathrm{Na}_{3} \mathrm{C}_{6} \mathrm{H}_{5} \mathrm{O}_{7} /\right.$ $\left.\mathrm{Na}_{2} \mathrm{CO}_{3} / \mathrm{NaH}_{2} \mathrm{PO}_{4} / \mathrm{K}_{2} \mathrm{HPO}_{4}\right)+\mathrm{H}_{2} \mathrm{O}$ aqueous biphasic systems were determined at $298 \mathrm{~K}$ and the aqueous biphasic systems were applied to extract the tryptophan for the first time. The extraction conditions of amino acid concentration, deep eutectic solvent amount, salt dosage, and the extraction temperature were investigated and optimized. Under the optimum conditions, the extraction efficiency of tryptophan can reach up to 86.72-93.88\% using deep eutectic solvent-based aqueous biphasic systems with the salt of $\mathrm{Na}_{2} \mathrm{CO}_{3}$, $\mathrm{Na}_{3} \mathrm{C}_{6} \mathrm{H}_{5} \mathrm{O}_{7}, \mathrm{NaH}_{2} \mathrm{PO}_{4}$ or $\mathrm{K}_{2} \mathrm{HPO}_{4}$. UV/Vis and fluorescence spectra confirmed that the conformation of tryptophan did not change after extraction. Deep eutectic solvent-based aqueous biphasic systems have great potential application in highly efficient extraction of biologically relevant amino acids and other substances.
\end{abstract}

Key words: Aqueous biphasic systems, extraction, deep eutectic solvent, tryptophan

In current liquid-liquid separation systems, waterimmiscible volatile organic solvents are widely used with their good extraction performance. But in the perspective of environmental issues of these hazardous solvents, there is a growing interest in finding greener replacements for liquid-liquid separation in industry and academic research. In recent years, aqueous biphasic systems (ABSs) aiming at avoiding the use of organic solvents as extractive phases have developed and been shown to be effective for separating organics ${ }^{[1,2]}$ metals $^{[3]}$, carbon nanotubes ${ }^{[4,5]}$, and biological compounds ${ }^{[6,7]}$. ABSs are composed of two aqueous-rich phases formed by polymer/polymer, polymer/salt, or salt/salt combinations. The basis of separation in ABSs is a direct result of the equilibration and selective distribution of target (bio) molecules between the two distinct aqueous phases.

Lately, ionic liquids (ILs, by definition salts which have melting points less than $100^{\circ}$ ) emerged as promising and alternative green replacements for ordinary organic solvents ${ }^{[8,9]}$, due to their chemical and thermal stabilities, negligible volatility, general non-flammability, and great dissolving ability for a wide variety of compounds ${ }^{[10,11]}$. Since 2003, Gutowski et $a l .{ }^{[12]}$ found imidazolium-based ILs can also form ABSs with inorganic salt of $\mathrm{K}_{3} \mathrm{PO}_{4}$. ABSs-based on ILs have received great attention in the field of liquid-liquid separations with their novel extractive ability and the feature of being environment friendly ${ }^{[13,14]}$. However, the synthesis of ILs is complex and expensive, which limit the large-scale industrial applications and development of ILs. As a new class of ILs or ILs analogue, the deep eutectic solvents (DES) has similar physical properties and phase behavior ${ }^{[15]}$ to traditional

This is an open access article distributed under the terms of the Creative Commons Attribution-NonCommercial-ShareAlike 3.0 License, which allows others to remix, tweak, and build upon the work non-commercially, as long as the author is credited and the new creations are licensed under the identical terms

Accepted 25 March 2019

Revised 29 November 2018

Received 21 September 2018

Indian J Pharm Sci 2019;81(3):448-455 
$\mathrm{ILS}^{[16,17]}$. DES can be synthesized easily using a certain molar ratio of two or three non-expensive components, which are capable of self-association through hydrogen bond interactions ${ }^{[18,19]}$. Also, the excellent sustainable and biodegradable properties of DES highlight their advantages as promising non-toxic green solvents ${ }^{[15,20]}$. DES has shown excellent performance in adsorption ${ }^{[21,22]}$, organics extraction ${ }^{[23,24]}$ and bioactive compounds separation ${ }^{[25,26]}$. So, as a candidate ILs, DES is a promising green solvent to form ABSs with potential great value in the field of extraction and separation.

Amino acids are building blocks of proteins and can be employed as elements or intermediates in antibodies, chelating agents and polypeptides ${ }^{[27-30]}$. These wide applications make amino acids play a vital role in daily routines and manufacture ${ }^{[31]}$. Separation and purification of amino acids are important and have crucial research value in human life. Traditional methods such as solid-liquid adsorption ${ }^{[32-34]}$, extraction with organic solvents ${ }^{[35-37]}$, ion-exchange ${ }^{[38]}$, centrifugation ${ }^{[39,40]}$ and chromatography ${ }^{[39,41]}$ are expensive and time consuming, and are not easily scalable ${ }^{[42]}$. Moreover, the operational environment is not mild in many cases, which may result in amino acid inactivation. So finding new methods for easy and low-cost extraction of amino acids along with bioactivity retention has become an instant issue for biotechnology. The use of environment friendly and economical DES-based ABSs would be a good strategy.

In this paper, choline chloride $(\mathrm{ChCl}) /$ polyethylene glycol-based DES was synthesized and characterized. A series of ABSs composed of the synthesized DES and salt $\left(\mathrm{Na}_{3} \mathrm{C}_{6} \mathrm{H}_{5} \mathrm{O}_{7}, \mathrm{Na}_{2} \mathrm{CO}_{3}, \mathrm{NaH}_{2} \mathrm{PO}_{4}\right.$, or $\left.\mathrm{K}_{2} \mathrm{HPO}_{4}\right)$ solutions were established and applied for the extraction of tryptophan for the first time. Some of the significant factors effecting the extraction, such as the species and amount of salts, the concentration of tryptophan, the dosage of DES, and the temperature were optimized. The chemical nature of tryptophan before and after extraction was investigated using $\mathrm{UV} / \mathrm{Vis}$ and fluorescence spectrometer.

\section{MATERIALS AND METHODS}

All reagents used were of analytical grade (AR) and purchased from Sinopharm Chemical Reagent Co., Ltd., Shanghai, China without further purification but polyethylene glycol 2000 (PEG, chemically pure) was dried under vacuum before use. Double-distilled water was used throughout the experiments. L-tryptophan with a purity $>99.0 \% \mathrm{w} / \mathrm{w}$ was employed to investigate the extraction capacity.

\section{Synthesis and characterization of DES:}

DES was synthesized by stirring two eutectic mixture at $110^{\circ}$ till a homogeneous, colorless liquid was formed. The investigated DES was based on $\mathrm{ChCl}$ and PEG with a certain mass ratio $(\mathrm{PEG}=50,60,70,80,90$, $100 \%$ ) according the process reported by Li et al. ${ }^{[43]}$. The structure of the synthetic DES was confirmed using elemental analyses, thermogravimetric analysis (TGA) and Fourier-transform infrared spectroscopy (FT-IR).

Elemental analysis was carried out on an Element analyzer (Flash1112A) by weighting $2.3 \mathrm{mg}$ samples in a tinfoil. TGA was done on STA-449C Jupiter (Netzsch Corporation, Germany). The sample was tested from room temperature to $800^{\circ}$ with a heating rate of $10^{\circ} / \mathrm{min}$ under air atmosphere with airflow of $60 \mathrm{l} / \mathrm{min}$. FT-IR spectra of samples were measured on a Nicolet Avatar-370 spectrometer at room temperature using the standard $\mathrm{KBr}$ disk method.

\section{Phase diagram:}

The phase diagrams were recorded by turbidimetric method under room temperature ${ }^{[44]}$. DES solution $(1.5 \mathrm{ml}, 50 \%$, w/w) was added into a $10 \mathrm{ml}$ centrifuge tube. Saturated solution of $\mathrm{Na}_{3} \mathrm{C}_{6} \mathrm{H}_{5} \mathrm{O}_{7}$ (or other salts) was added dropwise and shaken until the appearance of a cloudy solution. This was followed by dropwise addition of water to make the mixture clear again. The above process was repeated to obtain sufficient data to construct a liquid-liquid equilibrium phase diagram.

\section{Extraction of tryptophan:}

A certain amount of DES, salt $\left(\mathrm{Na}_{3} \mathrm{C}_{6} \mathrm{H}_{5} \mathrm{O}_{7}, \mathrm{Na}_{2} \mathrm{CO}_{3}\right.$, $\mathrm{NaH}_{2} \mathrm{PO}_{4}$, or $\mathrm{K}_{2} \mathrm{HPO}_{4}$ ) and tryptophan solution were added into graduated tubes, respectively. Afterwards, the biphasic solutions were left to equilibrate for 30 min (a time period established by shaking vigorously) to achieve a complete tryptophan partitioning between the two phases. The concentration of amino acid, in both phases, was determined on a UV/Vis spectrophotometer at a wavelength of $278 \mathrm{~nm}$. A calibration curve obtained in the range of $0-0.1 \mathrm{~g} / 1$ was $\mathrm{A}=25.52 \mathrm{C}+0.027\left(\mathrm{R}^{2}=0.9993\right)$, where $\mathrm{C}(\mathrm{g} / \mathrm{l})$ is the concentration of amino acid and A is the UV absorbance. Partitioning of tryptophan between the two phases were characterized by the partition coefficient $(\mathrm{K})$, phase volume ratio $(\mathrm{R})$, and extraction efficiency ( $\mathrm{E} \%)$, which can be calculated by 
the following Eqns. 1, 2 and 3, $\mathrm{K}=\mathrm{C}_{\mathrm{t}} / \mathrm{C}_{\mathrm{b}} ; \mathrm{R}=\mathrm{V}_{\mathrm{t}} / \mathrm{V}_{\mathrm{b}}$; $\mathrm{E} \%=\mathrm{C}_{\mathrm{t}} \mathrm{V}_{\mathrm{t}} /\left(\mathrm{C}_{\mathrm{t}} \mathrm{V}_{\mathrm{t}}+\mathrm{C}_{\mathrm{b}} \mathrm{V}_{\mathrm{b}}\right) \times 100$, where $\mathrm{C}_{\mathrm{t}}$ and $\mathrm{C}_{\mathrm{b}}(\mathrm{g} / \mathrm{l})$ are the concentrations of tryptophan in the DES-rich top phase and salt-rich bottom phase, respectively. $\mathrm{V}_{t}$ and $\mathrm{V}_{\mathrm{b}}(\mathrm{ml})$ stand for the volume of the top and bottom phase, respectively.

\section{RESULTS AND DISCUSSION}

A series of DESs were synthesized with different mass ratios of $\mathrm{ChCl}$ and $\mathrm{PEG}$, and the melting points were detected using a meldometer (fig. 1). DES had a minimum melting point at $60 \%$ of PEG mass fraction $(\mathrm{ChCl}: \mathrm{PEG}=2: 3, \mathrm{w} / \mathrm{w})$, and this DES with the mass ratio of 2:3 (ChCl:PEG) was chosen for the later investigation $^{[45]}$. Elemental analysis of the prepared DES is listed in Table 1. The analysis value was approximated with the calculated value. It indicated that there was no mass defect in the process of the reaction.

The TGA, DSC and DTG curves for DES, PEG and $\mathrm{ChCl}$ are shown in fig. 2. The decomposition of PEG and $\mathrm{ChCl}$ were 259.7 and $316.7^{\circ}$, respectively. After DES is formed, the weight loss was divided into two steps, which were just assigned to its two reactants. According to the DSC curves of DES, the first step was an endothermic process attributed to the thermolysis of PEG, while the second step was an exothermic process attributed to the thermolysis of $\mathrm{ChCl}$.

FT-IR spectra of the ChCl, PEG and DES are shown in fig. 3. The bands between 3000 and $2700 \mathrm{~cm}^{-1}$

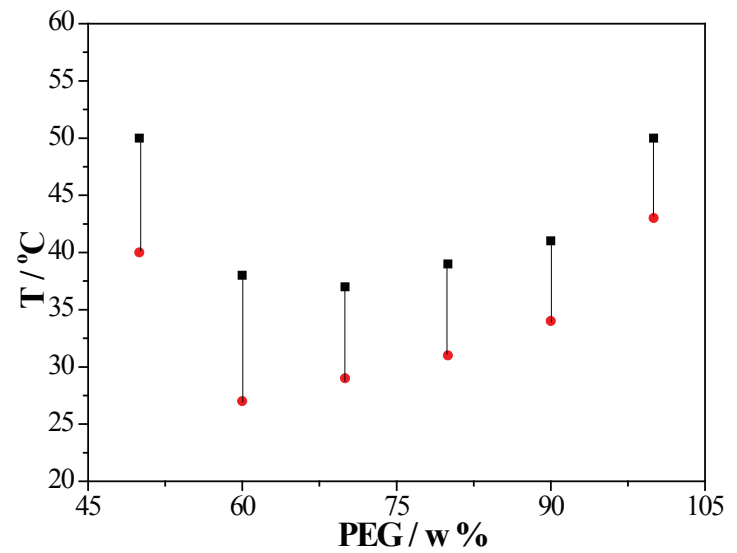

Fig. 1: Melting points of DES with different PEG mass fraction $(\bullet)$ Incipient melting point, ( $($ ) final melting point

TABLE 1: ELEMENTAL ANALYSIS OF C, H, N OF THE PREPARED DES

\begin{tabular}{lccc}
\hline DES & $\mathrm{C} \%$ & $\mathrm{H} \%$ & $\mathrm{~N} \%$ \\
\hline Calculated value & 49.47 & 9.28 & 1.75 \\
Analysis found & 49.01 & 9.38 & 1.62 \\
\hline
\end{tabular}
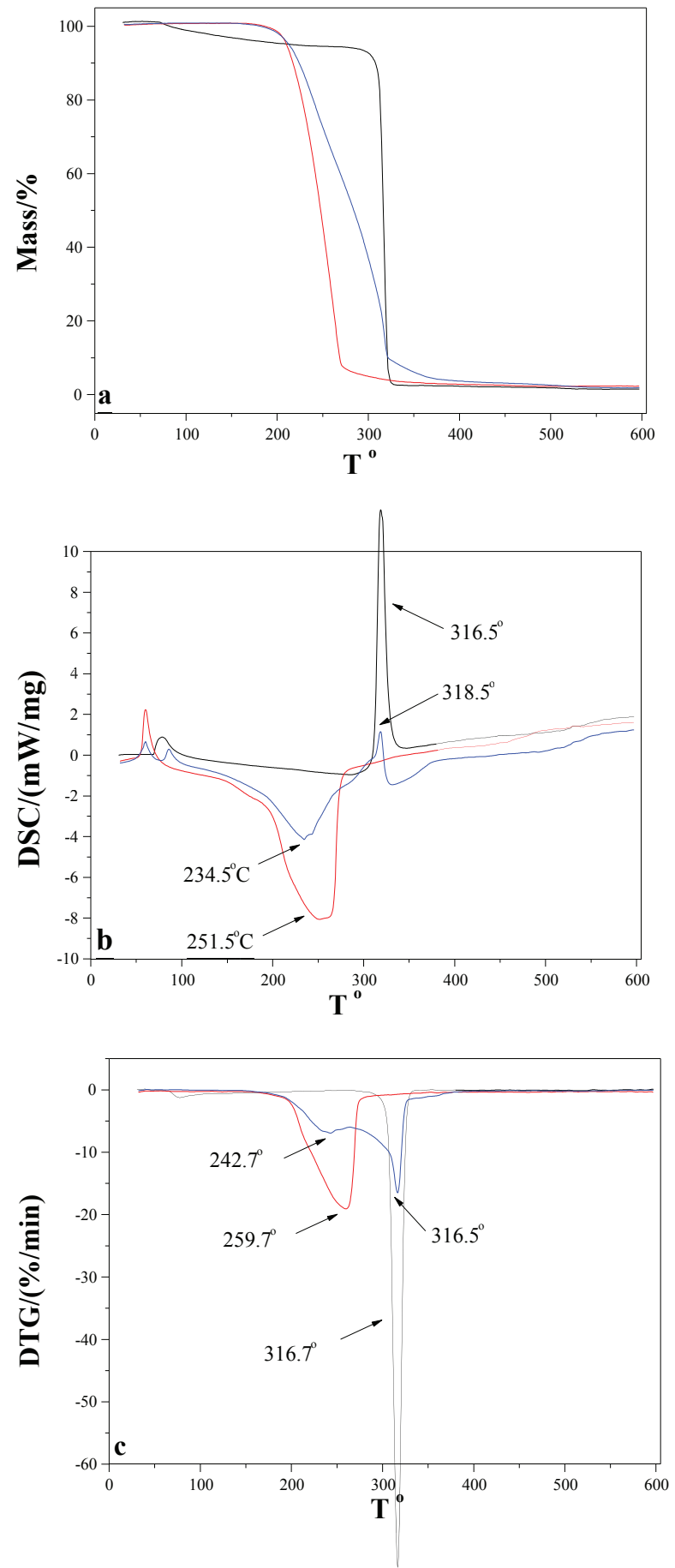

Fig. 2: (a) TGA, (b) DSC and (c) DTG curves for DES, PEG and $\mathrm{ChCl}$

(—) DES; (—) PEG; (-) ChCl

corresponded to the stretching vibration of $\mathrm{C}-\mathrm{H}$ in $\mathrm{ChCl}$ and DES. Compared with $\mathrm{ChCl}$, the redshift of the peak of $\mathrm{C}-\mathrm{O}$ (from 960 to $950 \mathrm{~cm}^{-1}$ ) in DES was clearly seen, indicated that large amount of the stable hydrogen bonds were formed ${ }^{[24]}$. The main characteristic peaks of $\mathrm{ChCl}$ and PEG could be observed in the FTIR spectrum of DES, which identified that functional groups of reactant were stable when the reaction was processing. 
Liquid-liquid equilibrium data were significant for the design of aqueous biphasic extraction process. In this study, the equilibrium compositions of the ABSs, DES (1) + salt $\left(\mathrm{Na}_{3} \mathrm{C}_{6} \mathrm{H}_{5} \mathrm{O}_{7}, \mathrm{Na}_{2} \mathrm{CO}_{3}, \mathrm{NaH}_{2} \mathrm{PO}_{4}\right.$, or $\left.\mathrm{K}_{2} \mathrm{HPO}_{4}\right)$ (2) $+\mathrm{H}_{2} \mathrm{O}$ (3), determined at $298 \mathrm{~K}$ are shown in fig. 4 . These binodal curves can provide the information about the concentration fractions of DES and salt required to form an ABS. The region above the curve represented the biphasic system, while the system was a homogeneous phase below the curve. In addition, larger biphasic region indicated stronger ability for the salts to undergo $\mathrm{ABS}^{[46]}$. It can be seen from fig. 4 that the phase-forming ability of salts followed the order: $\mathrm{Na}_{2} \mathrm{CO}_{3}>\mathrm{Na}_{3} \mathrm{C}_{6} \mathrm{H}_{5} \mathrm{O}_{7}>\mathrm{K}_{2} \mathrm{HPO}_{4}>\mathrm{NaH}_{2} \mathrm{PO}_{4}$.

The extraction efficiency of tryptophan was investigated in a series of ABSs employing $0.28 \mathrm{~g} / \mathrm{ml}$ of DES and $0.14 \mathrm{~g} / \mathrm{ml}$ of different salts of $\mathrm{Na}_{3} \mathrm{C}_{6} \mathrm{H}_{5} \mathrm{O}_{7}, \mathrm{Na}_{2} \mathrm{CO}_{3}$,

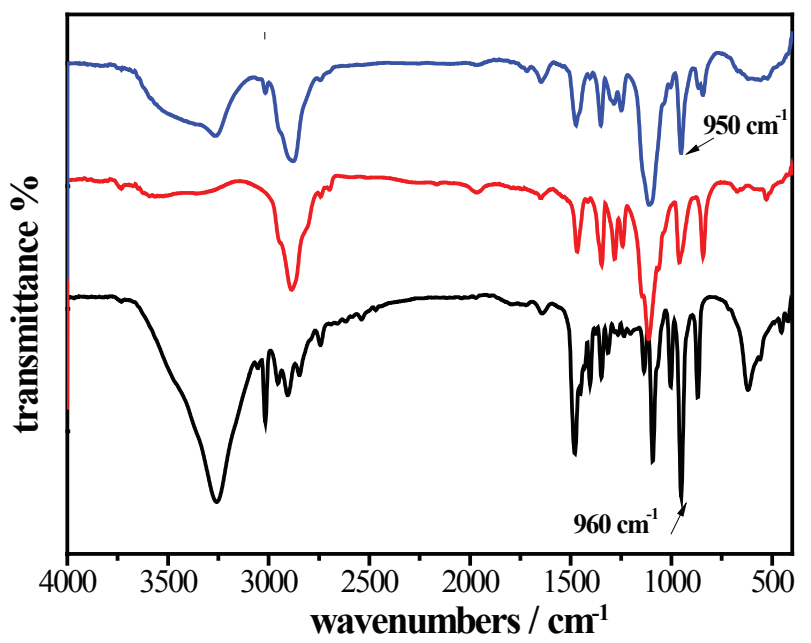

Fig. 3: FT-IR spectra of DES, PEG and $\mathrm{ChCl}$

(—) DES; (—) PEG; (-) ChCl

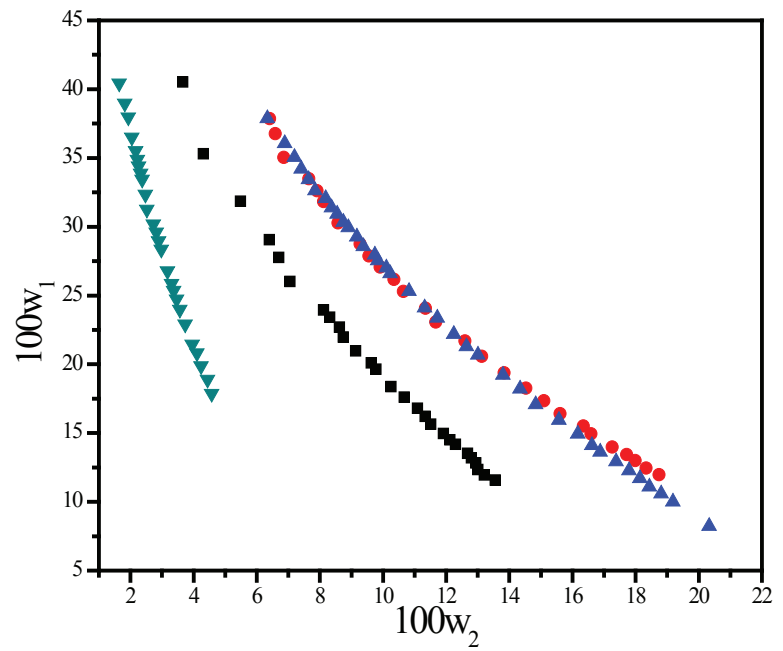

Fig. 4: Phase diagrams of DES-based ABSs with different salts Phase diagrams of DES-based ABSs with different salts (•) $\mathrm{K}_{2} \mathrm{HPO}_{4},(\Delta) \mathrm{NaH}_{2} \mathrm{PO}_{4},(\square) \mathrm{Na}_{3} \mathrm{C}_{6} \mathrm{H}_{5} \mathrm{O}_{7}$ and ( $\nabla$ ) $\mathrm{Na}_{2} \mathrm{CO}_{3}$
$\mathrm{NaH}_{2} \mathrm{PO}_{4}$ or $\mathrm{K}_{2} \mathrm{HPO}_{4}$. As shown in fig. 5a, it was obvious that DES- $\mathrm{Na}_{2} \mathrm{CO}_{3} \mathrm{ABS}$ showed the highest extraction efficiency of tryptophan, and the extraction efficiency in DES-based ABSs with different salt species followed the order of $\mathrm{Na}_{2} \mathrm{CO}_{3}>\mathrm{Na}_{3} \mathrm{C}_{6} \mathrm{H}_{5} \mathrm{O}_{7}>$ $\mathrm{K}_{2} \mathrm{HPO}_{4}>\mathrm{NaH}_{2} \mathrm{PO}_{4}$, which were in agreement with the phase-forming order mentioned previously.

Effect of tryptophan concentration on the extraction efficiency in series DES-based ABSs with different salts was investigated and shown in fig. 5b. Although there were some swings along the way, the extraction efficiency of tryptophan decreased slowly with the increase of the concentration of tryptophan in overall trend for these DES-based ABSs. The reason was proposed that both the formation of $\mathrm{ABS}$ and the extraction of the target are depended on the competition for the water molecule ${ }^{[47]}$. The massive addition of tryptophan will weaken the water affinity to the DES and cause the extraction of tryptophan decline in DESrich top phase in the ABSs. The optimum concentration of tryptophan was $0.05 \mathrm{~g} / 1$.

The amount of DES was a significant factor that influences the extraction of tryptophan for ABSs and the result is shown in Table 2. With the increase of DES, the extraction efficiency of tryptophan in DES-based ABSs with $\mathrm{Na}_{2} \mathrm{CO}_{3}, \mathrm{NaH}_{2} \mathrm{PO}_{4}, \mathrm{~K}_{2} \mathrm{HPO}_{4}$ and $\mathrm{Na}_{3} \mathrm{C}_{6} \mathrm{H}_{5} \mathrm{O}_{7}$ firstly continually increased, then reached the maximum values, and then decreased except DES- $\mathrm{Na}_{3} \mathrm{C}_{6} \mathrm{H}_{5} \mathrm{O}_{7}$ system. When the DES amount was more than $1.3 \mathrm{~g}$ $(0.46 \mathrm{~g} / \mathrm{ml})$, there was not enough water to dissolve the DES, and the bi-phase system can't be formed. This result indicated that DES could promote the extraction of tryptophan at a suitable range, and the optimum amount of DES is $0.28,0.46,0.40$ and $0.40 \mathrm{~g} / \mathrm{ml}$ for the four ABSs of DES- $\mathrm{Na}_{2} \mathrm{CO}_{3}, \mathrm{DES}-\mathrm{Na}_{3} \mathrm{C}_{6} \mathrm{H}_{5} \mathrm{O}_{7}$, DES- $\mathrm{NaH}_{2} \mathrm{PO}_{4}$ and DES-K $\mathrm{HPO}_{4}$, respectively.

The effect of the addition of salts on the miscibility of a given system is very complex. As the salts dissolve in solvent, the ions are surrounded by a layer of water molecules. In the ABS, different compositions possesses diverse ions, and different types of intermolecular interactions exist in the system ${ }^{[48]}$. Then the extraction target is added in the disordered system increasing another rival to compete the quantificational water molecules. As shown in Table 3, with the increase of the dosage of salt, the extraction efficiency of tryptophan changed regularly and reached the maximum values of $85.86,86.2,88.41$ and $91.55 \%$ at their optimum dosage conditions for DES-based ABSs with $\mathrm{Na}_{2} \mathrm{CO}_{3}$, 
$\mathrm{Na}_{3} \mathrm{C}_{6} \mathrm{H}_{5} \mathrm{O}_{7}, \mathrm{NaH}_{2} \mathrm{PO}_{4}$ and $\mathrm{K}_{2} \mathrm{HPO}_{4}$, respectively. What needs to be mentioned is that the aqueous biophase can't be formed when the salt amount is outside the extreme scope.

The extraction efficiencies of tryptophan in the four ABSs at temperatures ranging from 288-328 K were measured, and the results are shown in fig. $5 \mathrm{c}$. As the temperature increased from 288 to $328 \mathrm{~K}$, the extraction efficiencies decreased to various extents. The DES$\mathrm{Na}_{2} \mathrm{CO}_{3}$ system was more sensitive than the other three $\mathrm{ABSs}$, the decrement value could reach approximately $26 \%$ while the $\mathrm{Na}_{3} \mathrm{C}_{6} \mathrm{H}_{5} \mathrm{O}_{7}$ and $\mathrm{NaH}_{2} \mathrm{PO}_{4}$ systems reach about $15 \%$, the $\mathrm{K}_{2} \mathrm{HPO}_{4}$ system reach about $8 \%$. The possible reason might be that the water solubility of $\mathrm{Na}_{2} \mathrm{CO}_{3}$ is low and sensitive to temperature, which cause more tryptophan distributed into the salt-
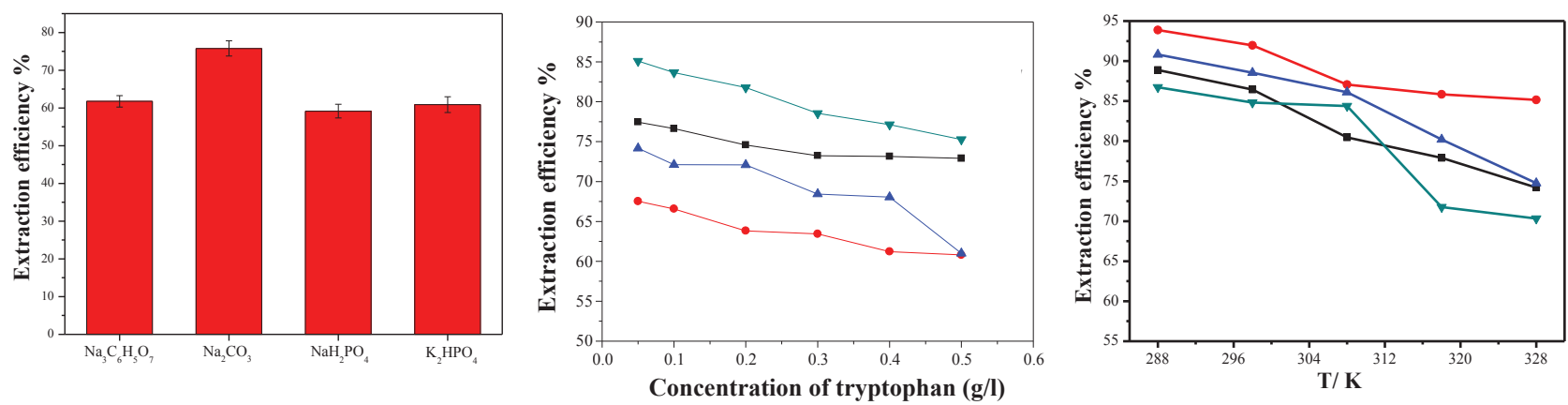

b.

Fig. 5: Effect of salt species, tryptophan concentration and temperature on extraction efficiency

Effect of (a) salt species, $\mathrm{C}_{\mathrm{DES}}: 0.28 \mathrm{~g} / \mathrm{ml}, \mathrm{C}_{\text {salt }}: 0.14 \mathrm{~g} / \mathrm{ml}, \mathrm{C}_{\text {tryptophan }}: 1.6 \mathrm{~g} / \mathrm{l}, 298 \mathrm{~K}$, (b) tryptophan concentration, ( $\left.-\nabla-\right) \mathrm{Na}_{2} \mathrm{CO}_{3}$, $(-\square-) \mathrm{Na}_{3} \mathrm{C}_{6} \mathrm{H}_{5} \mathrm{O}_{7},(-\Delta-) \mathrm{NaH}_{2} \mathrm{PO}_{4},(-\bullet-) \mathrm{K}_{2} \mathrm{HPO}_{4}$ and (c) temperature, (-๑) $\mathrm{K}_{2} \mathrm{HPO}_{4}\left(\mathrm{ABS}^{-1}\right),(-\Delta-) \mathrm{NaH}_{2} \mathrm{PO}_{4}\left(\mathrm{ABS}_{-}\right.$ 2), (一- $-\mathrm{Na}_{3} \mathrm{C}_{6} \mathrm{H}_{5} \mathrm{O}_{7}(\mathrm{ABS}-3),(-\nabla-) \mathrm{Na}_{2} \mathrm{CO}_{3}$ on the extraction efficiency of tryptophan

TABLE 2: EFFECT OF DES AMOUNT ON THE EXTRACTION EFFICIENCY OF TRYPTOPHAN

\begin{tabular}{|c|c|c|c|c|c|c|c|c|c|}
\hline DES $(\mathrm{g} / \mathrm{ml})$ & Salt $(\mathrm{g} / \mathrm{ml})$ & $K$ & $R$ & $E \%$ & $\mathrm{DES}(\mathrm{g} / \mathrm{ml})$ & Salt $(\mathrm{g} / \mathrm{ml})$ & $K$ & $R$ & $E \%$ \\
\hline \multicolumn{5}{|c|}{$\mathrm{Na}_{2} \mathrm{CO}_{3}$} & \multicolumn{5}{|c|}{$\mathrm{Na}_{3} \mathrm{C}_{6} \mathrm{H}_{5} \mathrm{O}$} \\
\hline 0.16 & 0.14 & 5.40 & 0.46 & 71.16 & 0.28 & 0.14 & 2.66 & 1.26 & 77.02 \\
\hline 0.20 & 0.14 & 4.56 & 0.56 & 71.72 & 0.32 & 0.14 & 2.68 & 1.30 & 77.70 \\
\hline 0.24 & 0.14 & 5.93 & 0.71 & 80.81 & 0.36 & 0.14 & 2.71 & 1.33 & 78.28 \\
\hline 0.28 & 0.14 & 6.33 & 0.92 & 85.35 & 0.40 & 0.14 & 2.73 & 1.48 & 80.16 \\
\hline 0.32 & 0.14 & 3.22 & 0.82 & 72.62 & 0.46 & 0.14 & 2.87 & 1.61 & 82.21 \\
\hline & & $\mathrm{NaH}_{2} \mathrm{PO}_{4}$ & & & & & $\mathrm{~K}_{2} \mathrm{HPO}_{4}$ & & \\
\hline 0.28 & 0.14 & 1.74 & 1.63 & 73.92 & 0.28 & 0.14 & 2.48 & 0.86 & 68.08 \\
\hline 0.32 & 0.14 & 1.87 & 1.71 & 76.18 & 0.32 & 0.14 & 3.58 & 1.17 & 80.73 \\
\hline 0.36 & 0.14 & 2.02 & 1.89 & 79.24 & 0.36 & 0.14 & 4.04 & 1.23 & 83.25 \\
\hline 0.40 & 0.14 & 2.33 & 2.26 & 84.04 & 0.40 & 0.14 & 5.09 & 1.25 & 86.42 \\
\hline 0.46 & 0.14 & 1.31 & 2.64 & 77.57 & 0.46 & 0.14 & 3.97 & 1.42 & 84.93 \\
\hline
\end{tabular}

TABLE 3: EFFECT OF SALT MASS ON THE EXTRACTION EFFICIENCY OF TRYPTOPHAN

\begin{tabular}{|c|c|c|c|c|c|c|c|c|c|}
\hline $\mathrm{DES}(\mathrm{g} / \mathrm{ml})$ & Salt $(\mathrm{g} / \mathrm{ml})$ & $K$ & $R$ & $E \%$ & DES $(\mathrm{g} / \mathrm{ml})$ & Salt $(\mathrm{g} / \mathrm{ml})$ & $K$ & $R$ & $E \%$ \\
\hline \multicolumn{5}{|c|}{$\mathrm{Na}_{2} \mathrm{CO}_{3}$} & \multicolumn{5}{|c|}{$\mathrm{Na}_{3} \mathrm{C}_{6} \mathrm{H}_{5} \mathrm{O} 7$} \\
\hline 0.28 & 0.05 & 3.87 & 0.99 & 79.30 & 0.46 & 0.10 & 1.81 & 1.90 & 77.47 \\
\hline 0.28 & 0.08 & 4.27 & 0.97 & 80.55 & 0.46 & 0.14 & 2.90 & 1.64 & 82.63 \\
\hline 0.28 & 0.11 & 5.81 & 0.95 & 84.66 & 0.46 & 0.18 & 3.92 & 1.57 & 86.20 \\
\hline 0.28 & 0.14 & 6.53 & 0.93 & 85.86 & 0.46 & 0.22 & 4.07 & 1.21 & 83.12 \\
\hline \multirow[t]{2}{*}{0.28} & 0.17 & 8.57 & 0.51 & 81.38 & 0.46 & 0.26 & 4.85 & 1.01 & 83.05 \\
\hline & & $\mathrm{H}_{2} \mathrm{PO}_{4}$ & & & & & & & \\
\hline 0.40 & 0.10 & 2.18 & 3.50 & 88.41 & 0.40 & 0.10 & 2.22 & 1.74 & 79.42 \\
\hline 0.40 & 0.14 & 2.32 & 2.28 & 84.10 & 0.40 & 0.14 & 4.94 & 1.28 & 86.34 \\
\hline 0.40 & 0.18 & 3.09 & 0.93 & 74.18 & 0.40 & 0.18 & 5.66 & 1.15 & 86.69 \\
\hline 0.40 & 0.22 & 1.99 & 0.93 & 64.85 & 0.40 & 0.22 & 9.11 & 0.92 & 89.34 \\
\hline 0.40 & 0.26 & 2.50 & 0.65 & 61.76 & 0.40 & 0.26 & 12.53 & 0.86 & 91.55 \\
\hline
\end{tabular}


rich phase with the temperature enhanced ${ }^{[49]}$. The increased temperature intensify the phenomenon of Brownian motion, and the molecules in the ABS are active to transfer between the two phase leading to homogeneous distribution ${ }^{[50]}$. ABS- 1 composition was $0.40 \mathrm{~g} / \mathrm{ml} \mathrm{DES}+0.26 \mathrm{~g} / \mathrm{ml} \mathrm{K}_{2} \mathrm{HPO}_{4}$; ABS-2 was $0.4 \mathrm{~g} / \mathrm{m}$ $1 \mathrm{DES}+0.10 \mathrm{~g} / \mathrm{ml} \mathrm{NaH}_{2} \mathrm{PO}_{4}$; ABS-3 was $0.46 \mathrm{~g} / \mathrm{ml}$ DES $+0.18 \mathrm{~g} / \mathrm{ml} \mathrm{Na}_{3} \mathrm{C}_{6} \mathrm{H}_{5} \mathrm{O}_{7}$ and ABS-4 was $0.28 \mathrm{~g} / \mathrm{ml}$ $\mathrm{DES}+0.14 \mathrm{~g} / \mathrm{ml} \mathrm{Na}_{2} \mathrm{CO}_{3} ; \mathrm{C}_{\text {tryptophan }}: 0.05 \mathrm{~g} / 1 ; 288-328 \mathrm{~K}$.

In order to investigate the tryptophan confirmation before and after extraction, UV/Vis and fluorescence spectra of tryptophan were studied ${ }^{[51]}$. Fig. 6a illustrates the UV/Vis spectra of tryptophan in water before extraction and in DES-rich phase of ABSs after extraction. It is clear that the curves appeared similar shape, the maximum absorption peak before and after extraction is at the same position of $278 \mathrm{~nm}$. Fig. $6 \mathrm{~b}$ shows the fluorescence emission spectra for tryptophan in the presence of DES at $\lambda_{\mathrm{ex}}=273 \mathrm{~nm}$, the characteristic peak of tryptophan in water and in DES-rich solution both appeared at $358 \mathrm{~nm}$. While the excitation spectra at $\lambda_{\mathrm{em}}=358 \mathrm{~nm}$ followed the similar situation. The results
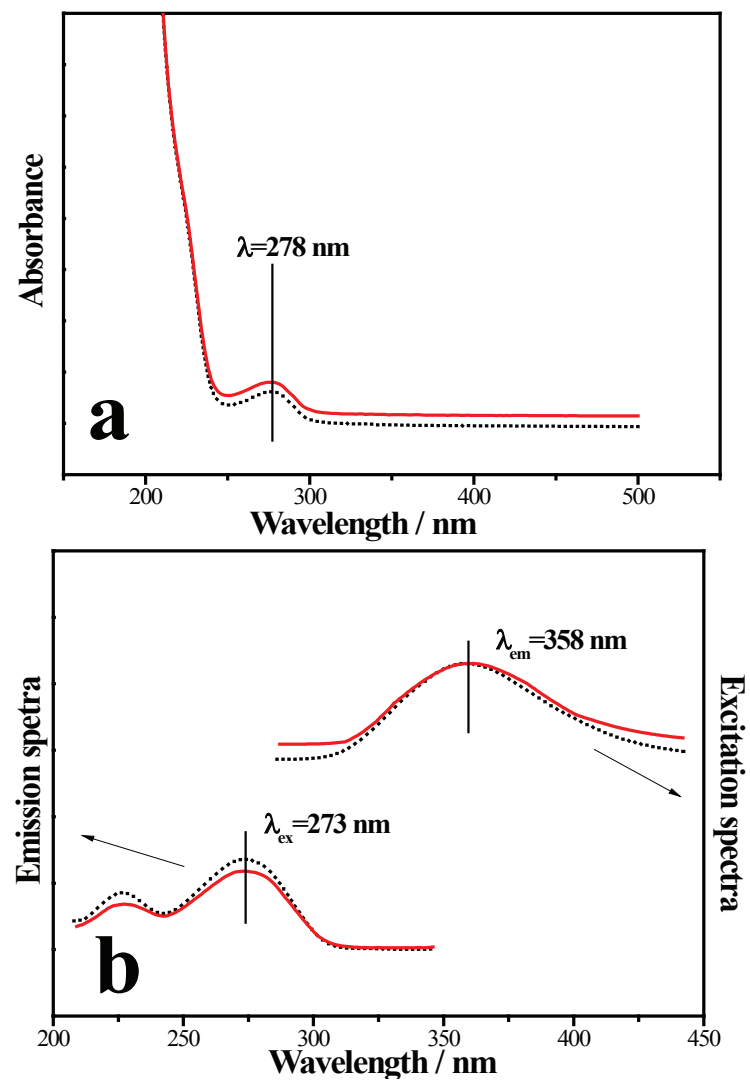

Fig. 6: UV/Vis and fluorescence spectra tryptophan before and after extraction

UV/Vis spectrum (a) and fluorescence spectrum (b) for tryptophan before and after extraction, (.....) tryptophan in pure water, (-) tryptophan in DES-rich phase indicated that there were no chemical interactions between the tryptophan and DES in the extraction process. The DES-based ABSs can provide a gentle environment for the extraction of tryptophan.

DES was successfully synthesized with proper mass ratios of $\mathrm{ChCl}$ and $\mathrm{PEG}$, and DES-salt $\left(\mathrm{Na}_{3} \mathrm{C}_{6} \mathrm{H}_{5} \mathrm{O}_{7}\right.$, $\mathrm{Na}_{2} \mathrm{CO}_{3}, \mathrm{NaH}_{2} \mathrm{PO}_{4}$, or $\mathrm{K}_{2} \mathrm{HPO}_{4}$ ) ABSs were established and applied for tryptophan extraction. DES- $\mathrm{Na}_{2} \mathrm{CO}_{3}$ ABS showed the strongest phase-forming ability. After the optimization of extraction conditions, the extraction efficiency of tryptophan can reach $93.88 \%$ (DES-K $\mathrm{HPO}_{4} \mathrm{ABS}$ ), $90.83 \%$ (DES-NaH $\mathrm{PO}_{4} \mathrm{ABS}$ ), $88.88 \%$ (DES- $\mathrm{Na}_{3} \mathrm{C}_{6} \mathrm{H}_{5} \mathrm{O}_{7}$ ABS) and $86.72 \%$ (DES$\mathrm{Na}_{2} \mathrm{CO}_{3}$ ABS), respectively, under the optimum conditions. Finally, UV/Vis and fluorescence spectra confirmed the structure of tryptophan had no change after extraction. DES-based ABSs can provide a mild environment and have potential applications in the high efficient extraction and purification of biological substances.

\section{Financial support sponsorship:}

Financial support for this investigation was given by the National Nature Science Foundation of China (Nos., 21506083, 21506080 and 21878133), Postdoctoral Science Foundation of China (2017M611726, 1601254C), and Scientific Research Foundation of Jiangsu University for the Senior Personnel (No., 15JDG176).

\section{Conflicts of interest:}

There are no conflicts of interest.

\section{REFERENCES}

1. Li Y, Wu Y, Chen K, Wu B, Ji L, Zhu J. Partition behavior of spiramycin in an aqueous two-phase system based on polyethylene glycol and sulfates. Sep Sci Technol 2018;53(3):496-502.

2. Pang J, Han C, Chao Y, Jing L, Ji H, Zhu W, et al. Partitioning Behavior of Tetracycline in Hydrophilic Ionic Liquids TwoPhase Systems. Sep Sci Technol 2015;50(13):1993-8.

3. $\mathrm{Wu} \mathrm{D,} \mathrm{Hu} \mathrm{L,} \mathrm{Wang} \mathrm{Y,} \mathrm{Wei} \mathrm{Q,} \mathrm{Yan} \mathrm{L,} \mathrm{Yan} \mathrm{T,} \mathrm{et} \mathrm{al.} \mathrm{EDTA}$ modified beta-cyclodextrin/chitosan for rapid removal of $\mathrm{Pb}(\mathrm{II})$ and acid red from aqueous solution. J Colloid Interface Sci 2018;523:56-64.

4. Fagan JA, Khripin CY, Batista CAS, Simpson JR, Haroz $\mathrm{EH}$, Walker ARH, et al. Isolation of Specific Small-Diameter Single-Wall Carbon Nanotube Species via Aqueous TwoPhase Extraction. Adv Mater 2014;26(18):2800-4.

5. Subbaiyan NK, Cambre S, Parra-Vasquez AN, Haroz EH, Doorn SK, Duque JG. Role of Surfactants and Salt in Aqueous Two-Phase Separation of Carbon Nanotubes toward Simple Chirality Isolation. ACS Nano 2014;8(2):1619-28. 
6. Nascimento MBd, Castro SdS, Veloso CM, Ilheu Fontan RdC, Soares do Nascimento DJ, Ramos Gandolfi OR, et al. Equilibrium data and thermodynamic studies of alphaamylase partition in aqueous two-phase systems. Fluid Phase Equilib 2018;463:69-79.

7. Pang JY, Sha XF, Chao YH, Chen GY, Han CR, Zhu WS, et al. Green aqueous biphasic systems containing deep eutectic solvents and sodium salts for the extraction of protein. RSC Adv 2017;7(78):49361-7.

8. Jiang W, Zheng D, Xun S, Qin Y, Lu Q, Zhu W, et al. Polyoxometalate-based ionic liquid supported on graphite carbon induced solvent-free ultra-deep oxidative desulfurization of model fuels. Fuel 2017;190:1-9.

9. Xun S, Zhu W, Chang Y, Li H, Zhang M, Jiang W, et al. Synthesis of supported SiW 12 O 40 -based ionic liquid catalyst induced solvent-free oxidative deep-desulfurization of fuels. Chem Eng J 2016;288:608-17.

10. Jiang W, Zhu W, Chang Y, Chao Y, Yin S, Liu H, et al. Ionic liquid extraction and catalytic oxidative desulfurization of fuels using dialkylpiperidinium tetrachloroferrates catalysts. Chem Eng J 2014;250:48-54.

11. Jiang $\mathrm{W}$, Zhu W, Li H, Wang X, Yin S, Chang Y, et al. Temperature-responsive ionic liquid extraction and separation of the aromatic sulfur compounds. Fuel 2015;140:590-6.

12. Gutowski KE, Broker GA, Willauer HD, Huddleston JG, Swatloski RP, Holbrey JD, et al. Controlling the aqueous miscibility of ionic liquids: aqueous biphasic systems of watermiscible ionic liquids and water-structuring salts for recycle, metathesis, and separations. J Am Chem Soc 2003;125:6632-3.

13. Yao T, Zang H, Yao S, Dai X, Song H. Measurement and correlation of phase equilibria in aqueous two-phase systems containing functionalized magnetic ionic liquids and potassium phosphate at different temperatures. J Mol Liq 2018;263:72-80.

14. Shukla SK, Pandey S, Pandey S. Applications of ionic liquids in biphasic separation: Aqueous biphasic systems and liquidliquid equilibria. J Chromatogr A 2018;1559:44-61.

15. Saravana PS, Ho TC, Chae SJ, Cho YJ, Park JS, Lee HJ, et al. Deep eutectic solvent-based extraction and fabrication of chitin films from crustacean waste. Carbohydr Polym 2018;195:622-30.

16. Haghbakhsh R, Raeissi S. Densities and volumetric properties of (choline chloride plus urea) deep eutectic solvent and methanol mixtures in the temperature range of 293.15-323.15 K. J Chem Thermodyn 2018;124:10-20.

17. Yilmaz E, Soylak M. A novel and simple deep eutectic solvent based liquid phase microextraction method for rhodamine $\mathrm{B}$ in cosmetic products and water samples prior to its spectrophotometric determination. Spectrochim Acta A Mol Biomol Spectrosc 2018;202:81-6.

18. Pena-Pereira F, Namiesnik J. Ionic Liquids and Deep Eutectic Mixtures: Sustainable Solvents for Extraction Processes. ChemSusChem 2014;7(7):1784-800.

19. Waite SL, Li H, Page AJ. NO2 Solvation Structure in Choline Chloride Deep Eutectic Solvents-The Role of the Hydrogen Bond Donor. J Phys Chem B 2018;122(15):4336-44.

20. Gano ZS, Mjalli FS, Al-Wahaibi T, Al-Wahaibi Y, AlNashef IM. Solubility of Thiophene and Dibenzothiophene in Anhydrous FeCl3- and ZnCl2-Based Deep Eutectic Solvents. Ind Eng Chem Res 2014;53(16):6815-23.

21. Lopez-Salas N, Jardim EO, Silvestre-Albero A, Gutierrez MC, Ferrer ML, Rodriguez-Reinoso F, et al. Use of Eutectic
Mixtures for Preparation of Monolithic Carbons with CO2Adsorption and Gas-Separation Capabilities. Langmuir 2014;30(41):12220-8.

22. Chao YH, Zhu WS, Wu XY, Hou FF, Xun SH, Wu PW, et al. Application of graphene-like layered molybdenum disulfide and its excellent adsorption behavior for doxycycline antibiotic. Chem Eng J 2014;243:60-7.

23. Xu H, Zhang DD, Wu FM, Wei XF, Zhang J. Deep desulfurization of fuels with cobalt chloride-choline chloride/ polyethylene glycol metal deep eutectic solvents. Fuel 2018;225:104-10.

24. Zhu WS, Wang C, Li HP, Wu PW, Xun SH, Jiang W, et al. One-pot extraction combined with metal-free photochemical aerobic oxidative desulfurization in deep eutectic solvent. Green Chem 2015;17(4):2464-72.

25. Zounr RA, Tuzen M, Deligonul N, Khuhawar MY. A highly selective and sensitive ultrasonic assisted dispersive liquid phase microextraction based on deep eutectic solvent for determination of cadmium in food and water samples prior to electrothermal atomic absorption spectrometry. Food Chem 2018;253:277-83.

26. Makos P, Fernandes A, Przyjazny A, Boczkaj G. Sample preparation procedure using extraction and derivatization of carboxylic acids from aqueous samples by means of deep eutectic solvents for gas chromatographic-mass spectrometric analysis. J Chromatogr A 2018;1555:10-9.

27. Ali SS, Morsy R, Elzawawy NA, Fareed MF, Bedaiwy MY. Synthesized zinc peroxide nanoparticles ( $\mathrm{ZnO} 2-\mathrm{NPs}$ ): a novel antimicrobial, anti-elastase, anti-keratinase, and antiinflammatory approach toward polymicrobial burn wounds. Int J Nanomedicine 2017;12:6059-73.

28. Ruan L, Shen Y, Lu Z, Shang D, Zhao Z, Lu Y, et al. Roles of partitioning-defective protein 6 (Par6) and its complexes in the proliferation, migration and invasion of cancer cells. Clin Exp Pharmacol Physiol 2017;44(9):909-13.

29. Wang N, Zhu F, Chen K. 1-deoxynojirimycin: Sources, extraction, analysis and biological functions. Nat Prod Commun 2017;12(9):1521-6.

30. Li CP, Li Z, Wang AL, Yin JM, Wang J, Li HX, et al. Aqueous two phase extraction process of tryptophan based on functionalized ionic liquids. RSC Adv 2013;3(18):6356-61.

31. Wan JY, Fan Y, Yu QT, Ge YZ, Yan CP, Alolga RN, et al. Integrated evaluation of malonyl ginsenosides, amino acids and polysaccharides in fresh and processed ginseng. J Pharm Biomed Anal 2014;107:89-97.

32. Hou J, Sun E, Zhang ZH, Wang J, Yang L, Cui L, et al. Improved oral absorption and anti-lung cancer activity of paclitaxel-loaded mixed micelles. Drug Deliv 2017;24(1):261.

33. Li H, Zhu W, Zhu S, Xia J, Chang Y, Jiang W, et al. The selectivity for sulfur removal from oils: An insight from conceptual density functional theory. AIChE J 2016;62(6):2087-100.

34. Zhang M, Wei Y, Li R, Zhu W, Li H, Zhang Q, et al. Magnetic POM-based mesoporous silica for fast oxidation of aromatic sulfur compounds. Fuel 2017;209:545-51.

35. Sun X, Deng Q, Liang Z, Liu Z, Geng H, Zhao L, et al. Cigarette smoke extract induces epithelial-mesenchymal transition of human bladder cancer T24 cells through activation of ERK1/2 pathway. Biomed Pharmacother 2016;86:457-65.

36. Li F, Raza A, Wang YW, Xu XQ, Chen GH. Optimization of Surfactant-Mediated, Ultrasonic-assisted Extraction of Antioxidant Polyphenols from Rattan Tea (Ampelopsis 
grossedentata) Using Response Surface Methodology. Pharmacogn Mag 2017;13(51):446-53.

37. Yang L, Qu H, Mao G, Zhao T, Li F, Zhu B, et al. Optimization of subcritical water extraction of polysaccharides from Grifola frondosa using response surface methodology. Pharmacogn Mag 2013;9(34):120.

38. Liu H, Liu D, Chen C, He Y, Zhu F, Zhang P, et al. Preparation and Evaluation of Carbinoxamine Maleate Sustained Release Suspensions with Ion Exchange Resin as the Carriers. Lat Am J Pharm 2017;36(4):797-809.

39. You Q, Yin X, Zhao Y, Jiang Z. Extraction and purification of polysaccharides from pine medicinal mushroom, Tricholoma matsutake (higher Basidiomycetes) fruit bodies. Int J Med Mushrooms 2014;16(2):149-60.

40. Feng W, Zhao T, Zhou Y, Li F, Zou Y, Bai S, et al. Optimization of enzyme-assisted extraction and characterization of collagen from Chinese sturgeon (Acipenser sturio Linnaeus) skin. Pharmacogn Mag 2013;9(1):32-7.

41. Tang X, Yan L, Jing G, Ge H, Yang H, Na L. Optimization of extraction process and investigation of antioxidant effect of polysaccharides from the root of Limonium sinense Kuntze. Pharmacogn Mag 2011;7(27):186-92.

42. Yan JK, Wang YY. Random-centroid optimization of ultrasound-assisted extraction of polysaccharides from Cordyceps sinensis mycelium. Curr Top Nutraceutical Res 2015;13(4):167-71.

43. Li CP, Li D, Zou SS, Li Z, Yin JM, Wang AL, et al. Extraction desulfurization process of fuels with ammonium-based deep eutectic solvents. Green Chem 2013;15(10):2793-9.

44. Pei Y, Li Z, Liu L, Wang J. Partitioning behavior of amino acids in aqueous two-phase systems formed by imidazolium ionic liquid and dipotassium hydrogen phosphate. J Chromatogr A 2012;1231:2-7.

45. Abbott AP, Cullis PM, Gibson MJ, Harris RC, Raven E. Extraction of glycerol from biodiesel into a eutectic based ionic liquid. Green Chem 2007;9(8):868-72.

46. Abdolrahimi S, Nasernejad B, Pazuki G. Influence of process variables on extraction of Cefalexin in a novel biocompatible ionic liquid based-aqueous two phase system. Phys Chem Chem Phys 2015;17(1):655-69.

47. Trindade JR, Visak ZP, Blesic M, Marrucho IM, Coutinho JAP, Lopes JNC, et al. Salting-out effects in aqueous ionic liquid solutions: Cloud-point temperature shifts. J Phys Chem B 2007;111(18):4737-41.

48. Ventura SPM, Neves CMSS, Freire MG, Marrucho IM, Oliveira J, Coutinho JAP. Evaluation of Anion Influence on the Formation and Extraction Capacity of IonicLiquid-Based Aqueous Biphasic Systems. J Phys Chem B 2009; 113(27):9304-10.

49. Cao Y, Xing H, Yang Q, Li Z, Chen T, Bao Z, et al. Biphasic Systems That Consist of Hydrophilic Ionic Liquid, Water, and Ethyl Acetate: The Effects of Interactions on the Phase Behavior. Ind Eng Chem Res 2014;53(26):10784-90.

50. Chen J, Wang Y, Zeng Q, Ding X, Huang Y. Partition of proteins with extraction in aqueous two-phase system by hydroxyl ammonium-based ionic liquid. Anal Methods 2014;6(12):4067-76.

51. Du Z, Yu YL, Wang JH. Extraction of proteins from biological fluids by use of an ionic liquid/aqueous two-phase system. Chemistry 2007;13(7):2130-7. 